\title{
Contrasting years of prey levels, feeding conditions and mortality of larval walleye pollock Theragra chalcogramma in the western Gulf of Alaska
}

\author{
Kevin M. Bailey, Michael F. Canino, Jefirey M. Napp, Stella M. Spring, \\ Annette L. Brown
}

Alaska Fisheries Science Center, National Oceanic and Atmospheric Administration, 7600 Sand Point Way NE, Seattle, Washington 98115 , USA

\begin{abstract}
Walleye pollock in Shelikof Strait, Gulf of Alaska, spawn in an area with strong interannual differences in the oceanic environment. Feeding conditions and mortality of walleye pollock larvae in Shelikof Strait were compared in 2 consecutive years of markedly contrasting oceanographic conditions. In 1990, winds were relatively calm, and a large eddy was formed in the lower portion of the strait; walleye pollock larvae were found concentrated in this eddy feature. In 1991, winds were very strong and sea surface temperatures were anomalously cold. Flow through the Shelikof region was strong in that year, and larvae were sparse. In 1990, copepod naupliar abundance was high throughout the study area. There were no geographic differences in feeding intensity of larvae, RNA content or larval growth. In 1991 the major differences occurred between inshore and of fshore stations. Comparing conditions in 1990 and 1991, naupliar abundance, larval feeding intensity, RNA content and length-atage were all low in the stormy conditions of 1991. In 1991 estimated mortality was significantly higher than that measured in 1990, although part of the loss could have been due to strong advection out of the area. Survival of expatriated larvae is discussed in light of very low juvenile abundances in 1991. This study shows the dramatic effect of environmental conditions on early larval survival rates.
\end{abstract}

KEY WORDS: Fish larvae $\cdot$ Walleye pollock $\cdot$ Feeding $\cdot$ Nutritional condition - Mortality

\section{INTRODUCTION}

Whether the concentration of prey in the ocean varies enough to affect larval fish nutritional condition and mortality is a controversial subject. Some studies report that prey concentrations may not be associated with survival, condition or abundance patterms of fish larvae (Rice et al. 1987, Taggart \& Leggett 1987, Owen et al. 1989, Thompson \& Harrop 1991, Bollens et al. 1992, McGurk et al. 1993). Other studies report that average prey concentrations may limit larval growth (Shelbourne 1957, Cohen \& Lough 1983, Gadomski \& Boehlert 1984, Fortier \& Gagne 1990, Fossum \& Moksness 1993). As noted by Mullin (1993), single point experiments are not sufficient tests of the importance of larval feeding. Various environmental conditions or features have been linked to prey concentrations and the feeding success of marine fish larvae. Some of these conditions and features include light intensity (Heath 1989), frontal zones (Kiørboe et al. 1988, Munk 1993), storms or turbulence (Lasker 1975, Tilseth \& Ellertsen 1984, Heath 1989, Sundby \& Fossum 1990, Maillet \& Checkley 1991) and density stratification (Govoni et al. 1985, Buckley \& Lough 1987. Coombs et al. 1992)

The effect of seasonal variability of larval prey concentrations on the growth or nutritional condition of larval walleye pollock Theragra chalcogramma has been demonstrated (Haldorson et al. 1989, Canino et al. 1991). Reduced concentrations of copepod nauplii early in the season were related to low indices of larval feeding and nucleic acid concentrations (Canino et al. 1991). In that study, an area of relatively good feeding conditions was subsequently identified as an eddy region (Bograd et al. 1994). Later in the season, feeding conditions were good throughout the region. In comparison, rela- 
trvely little has been reported on the differences in prey concentration between years and the resulting effects on larval feeding and mortality

In the western Gulf of Alaska, walleye pollock spawning is concentrated in space and time. Studies of pollock in the Fisheries Oceanography Coordinated Investigations (FOCI) program, a collaborative effort between biologists, oceanographers and meteorologists, are tımed to take advantage of this concentrated spawning and to follow the main aggregation of larvae as they drift downstream (Hinckley et al. 1991). The major spawning is in the southwest portion of Shelikof Stralt, Gulf of Alaska, (Fig. 1) and occurs mostly during a 2 wk penod in early Apnl (Kendall \& Picquelle 1990). Eggs are located deep in the water column and hatching larvae rise into the upper $60 \mathrm{~m}$ layer (Kendall et al. 1994) After yolk absorption, larvae predominantly consume copepod nauplii and eggs (Kendall et al. 1987. Canino et al. 1991). Larvae are transported southwestward in the Alaska Coastal Current.

The main objective of this study was to compare larval feeding conditions and mortality in 2 consecutıve years of markedly contrasting oceanographic conditions. In 1990, winds were relatively calm, and a large eddy was formed in the lower portion of Shelikof Strait; walleye pollock larvae were found concentrated in this eddy feature. In 1991, winds were very strong and water tempertures were anomalously cold. As we report here, flow through the Shelikof region was particularly strong in that year and no eddies or larval 'patches' were located. A secondary objective of this study was to compare conditions between oceanographic environments, specifically inside and outside the 1990 eddy region and between inshore and offshore regions. Biological measurements reported here include: naupliar concentrations, larval gut fullness, nucleic acid content, growth rates estimated from otolith increments, larval distribution and mortality patterns.

\section{METHODS}

Larval pollock were sampled from the RV 'Miller Freeman' during 4 cruises in 1990 and 1991. Details of the cruises are given in Table 1.

Surveys were designed to sample the same cohort of larvae on 2 consecutive cruises. The basic survey design was similar to that used in previous studies (Hinckley et al. 1993). Given the historical pattern of variance in larval abundance (determined from cruises conducted at simular times in 1986 and 1987), statistical power analyses have indicated that for a power, $\beta$ (the probability of correctly rejecting a false null hypothesis). of 0.8 and 0.95 a typical sample size of 80 stations per cruse separated by a typical duration of $20 \mathrm{~d}$

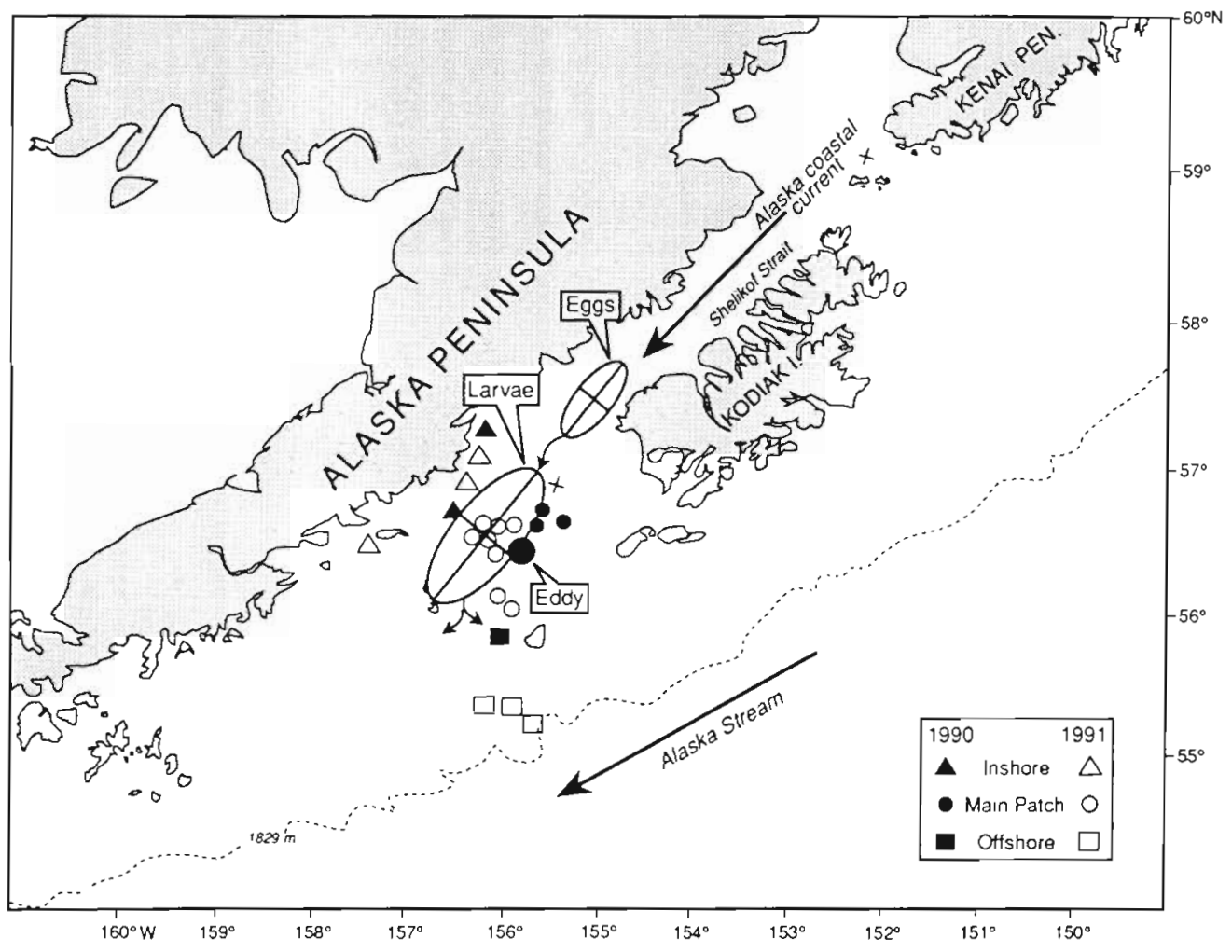

Fig. 1 Shelikof Strait region and location of sampling stations in 1990 and 1991. Additional sea valley and patch stations from Table 2 are in the near vicinity of circles shown. Average walleye pollock Theragra chalcogramma egg (April) and larval (May) distributions (from Kendall \& Picquelle 1990) are shown. ( $x$ ) Microzooplankton samples from Shelikof Strait entrance and upstream locations referred to in Table 2 ; (----) $1829 \mathrm{~m}$ bottom depth isoline (1000 fm) 
Table 1. Summary of survey information for 1990 and 1991

\begin{tabular}{|c|c|c|c|c|c|c|c|}
\hline \multirow[t]{2}{*}{ Year } & \multirow{2}{*}{$\begin{array}{c}\text { Survey } \\
\text { dates }\end{array}$} & \multirow{2}{*}{$\begin{array}{c}\text { Mean } \\
\text { survey date }\end{array}$} & \multirow{2}{*}{$\begin{array}{c}\text { No. } \\
\text { of stations }\end{array}$} & \multicolumn{4}{|c|}{ Larval walleye pollock samples } \\
\hline & & & & $\begin{array}{c}\text { No. of } \\
\text { age samples }\end{array}$ & $\begin{array}{l}\text { Age } \\
\text { range (d) }\end{array}$ & $\begin{array}{c}\text { No. of } \\
\text { length samples }\end{array}$ & $\begin{array}{l}\text { Length } \\
\text { range }(\mathrm{mm})\end{array}$ \\
\hline 1990 & 6-15 May & 10 May & 66 & 165 & $1-20$ & 458 & $4.0-11.5$ \\
\hline 1990 & 27 May-5 Jun & 1 Jun & 114 & 143 & $6-63$ & 1594 & $4.5-15.0$ \\
\hline 1991 & $30 \mathrm{Apr}-15 \mathrm{May}$ & 6 May & 60 & 165 & $1-12$ & 172 & $2.5-8.5$ \\
\hline 1991 & 17-25 May & 22 May & 75 & 117 & $5-39$ & 308 & $4.5-12.5$ \\
\hline
\end{tabular}

would detect mortality rates of 0.014 and $0.018 \mathrm{~d}^{-1}$. respectively.

Survey boundaries were based on location of spawners and egg distribution patterns determined from prior cruises, as well as relative movement of drifters released during earlier cruises. Satellite-tracked drifters were released in areas of relatively high larval abundance. Drifters were of the 'holey-sock' design and were drogued at a mean depth of $40 \mathrm{~m}$. Grid stations were established and surveyed as rapidly as possible, generally within 4 to $7 \mathrm{~d}$. On the second survey of the sequence, the sampling grid was extended downstream in response to real-time knowledge of drifter movement.

Walleye pollock larvae were sampled with bongo tows. Bongo nets sample walleye pollock larvae efficiently to a length of about $18 \mathrm{~mm}$ (Shima \& Bailey 1994) as they are relatively sluggish swimmers. Given a mean growth rate of about $0.2 \mathrm{~mm} \mathrm{~d}^{-1}$ (Yoklavich \& Bailey 1990), larvae sampled on the early May cruise at about $5.5 \mathrm{~mm}$ would be about $10 \mathrm{~mm} 20 \mathrm{~d}$ later. Over these length ranges, there are no day/night differences in bongo catch rates or length frequencies (Hinckley et al. 1993, Shima \& Bailey 1994).

Tows were double oblique to $100 \mathrm{~m}$ (or to $10 \mathrm{~m}$ off bottom in shallower stations) using a $60 \mathrm{~cm}$ frame and $333 \mu \mathrm{m}$ mesh nets with hard codends (Posgay \& Marak 1980 ) on the early May cruises in both years. In the late May cruises, tows were conducted to $100 \mathrm{~m}$ with $60 \mathrm{~cm}$ frame and $505 \mu \mathrm{m}$ mesh nets. Net retrieval was at $20 \mathrm{~m}$ $\mathrm{min}^{-1}$ while the ship maintained a speed of $-100 \mathrm{~cm}$ $\mathrm{s}^{-1}$. Flow meters were mounted in the mouth of the net to determine filtered volume. For standard bongo tows, the contents of one codend were fixed in $5 \%$ formalin seawater for quantitative sorting in the laboratory, and the contents of the other codend were quickly sorted over ice and larvae were fixed in $95 \%$ ethanol for otolith ageing.

Standard bongo samples were sorted at the Polish Plankton Sorting Center, Szczecin, Poland. Walleye pollock larvae were identified, enumerated and a subsample measured for standard length (SL). Identification was then verified in our Seattle, Washington, USA, laboratory.
Live tows (vertical tows to $50 \mathrm{~m}$ with solid codends) were conducted to obtain samples for RNA analysis (larvae were measured for SL immediately over seawater ice) and frozen at $-75^{\circ} \mathrm{C}$; larvae from live tows were also fixed in $5 \%$ formalin for gut samples.

Biological and physical measurements were made to assess conditions inside and outside regions of high larval pollock abundance. Measurements included conductivity and temperature depth profiles from surface to near bottom and concurrent sampling of nutrients, chlorophyll (1991 only), and microzooplankton on the 'upcast' using a water bottle rosette and $10 \mathrm{l}$ Niskin bottles. The operational demarcation of the mixed layer used here is the depth where the temperature was $0.5^{\circ} \mathrm{C}$ less than the average temperature in the top $3 \mathrm{~m}$. Nutrients were frozen for later analysis using an AutoAnalyzer (University of Washington Routine Chemistry Laboratory; Whitledge et al. 1981). Water for extracted chlorophyll a (chl a) was filtered onto Whatman GF/F filters, placed in microcentrifuge tubes and frozen at $-75^{\circ} \mathrm{C}$ for later fluorometric analysis. Water for microzooplankton was sieved through small conical nets (41 $\mu \mathrm{m}$ mesh); material retained by the nets was washed with filtered seawater into sample vials and preserved in $5 \%$ buffered formalin. The samples were later stained with Rose Bengal to facilitate counting

Microzooplankton samples from 1990 and 1991 were treated differently. In 1990, each individual water bottle sample was examined for all potential prey items (Incze \& Ainaire 1994, their Table 1); naupliar length \& width (total body excluding appendages) or egg radius was measured using a video image analysis system. The standard deviation of replicate length measurements was $4 \mu \mathrm{m}$ for a $500 \mu \mathrm{m}$ long nauplius. In 1991, water bottle samples were 'integrated' to reduce the analysis time and to approximate the integration scale of the larval condition tows. Integration was accomplished in the laboratory by (Folsom) splitting all samples within a cast; one half of each sample was used to create the 'integrated' sample and the other half was archived. Thus, 6 halves ( 1 from each depth) were combined into 1 physical sample. A subsample of the 
'integrated' sample was prepared to yield ca 100 nauplii. Prey items were measured as in 1990 with the image analysis system. 'Biovolume' calculations for 1990 and 1991 assumed that naupliar volume was best represented by a cylinder whose length was the total length of the nauplius and whose diameter was the widest distance across its carapace.

Otolith ageing techniques are described in Yoklavich \& Bailey (1990). Previous studies of larval walleye pollock have demonstrated that under normal healthy conditions increments are deposited daily, but during starvation they may be difficult to distinguish or are deposited less frequently (Nishimura \& Yamada 1984, Bailey \& Stehr 1988).

The nucleic acid contents of pollock larvae were determined by a sequential enzymatic digestion procedure modified from Bentle et al. (1981) as described by Canino et al. (1991) and Canino (1994). The method is based upon the enhanced fluorescence of the dye ethidium bromide when bound to nucleic acids. Fluorescence of the nucleic acid-fluorochrome complex is measured before and after sequential additions of RNase and DNase. Total sample fluorescence is partitioned into DNA and RNA components and the nucleic acid concentrations are calculated by difference after enzymatic degradation. We report RNA content standardized for biomass using SL. RNA is the more direct precursor for protein synthesis and growth than DNA or RNA/DNA, and changes in RNA are more dramatic in response to feeding conditions than in DNA (Buckley 1980, 1981, Canino 1994). Loss or accumulation of RNA has the more immediate effect upon protein growth since changes in DNA are more conservative (Buckley 1981, Canino 1994). Using SL as a standardization for biomass allows us a direct comparison with gut contents, otolith growth and mortality, which are length based.

Gut contents of pollock larvae were measured from samples collected at (or near) stations where microzooplankton and nucleic acid samples were taken. SL (tip of snout to end of notochord) was measured to the nearest $0.08 \mathrm{~mm}$ with an ocular micrometer prior to preservation in $5 \%$ buffered formalin in seawater. In some cases where live lengths were not obtained, larvae were measured after fixation in formalin and lengths were corrected for shrinkage (Live SL = Fixed SL/0.90; Theilacker \& Porter in press). The entire digestive tract was later excised and dissected in the laboratory to enumerate ingested prey. Loss of hindgut contents through defecation occurs in response to netcapture and preservation (Canino \& Bailey in press). Therefore, only the contents of the larval midgut were counted for analysis.

Differences in slopes and intercepts of length-at-age, RNA content-at-length, and gut content-at-length relationships were tested by an ANCOVA procedure using larval length as the covariate. In this type of test, the differences in slopes are assessed by a preliminary ANOVA including interaction terms. If differences were found, Tukey's test (Zar 1984) was utilized to determine which slopes were different. If slopes were not significantly different, interaction terms were dropped and differences in intercepts were determined by standard ANCOVA.

Mean mortalities and variances were estimated following the methods detailed in Hinckley et al. (1993) with minor modifications. Briefly, age-length keys, based on age intervals of $3 \mathrm{~d}$ ( $3 \mathrm{~d}$ cohorts) and $0.5 \mathrm{~mm}$ length intervals, were generated and applied to the larger length frequency samples to generate an age distribution for each station. Larval lengths from different fixatives were standardized to live prefixed lengths (Hinckley et al. 1993). Because surveys are not synoptic and larvae are collected throughout the survey period, ages and lengths of larvae were standardized to the mean survey date for each cruise by fitting each survey's age and length data to a growth model (Brown \& Bailey 1992). Hatch dates in 3 d intervals were calculated from standardized age and mean survey date. Standardized numbers (no. $10 \mathrm{~m}^{-2}$ were determined from the area represented by each station, and hatch date abundance was summed over all stations.

Mortality rates $\left(z_{a}\right)$ were estimated based on the formula:

$$
z_{a}=\frac{\ln \left(C_{1, a}\right)-\ln \left(C_{2, a}\right)}{t_{2}-t_{1}}
$$

where $C_{1, a}$ is the abundance of cohort $a$ in the first survey and $t_{2}-t_{1}$ is the duration between surveys.

The variance of the mortality rate was estimated using the delta method:

$$
\operatorname{Var}\left(z_{a}\right)=\frac{1}{\left(t_{2}-t_{1}\right)^{2}} \cdot\left[\frac{\operatorname{Var}\left(C_{1, a}\right)}{C^{2} 1, d}+\frac{\operatorname{Var}\left(C_{2, a}\right)}{C^{2} 2, a}\right]
$$

\section{RESULTS}

\section{Oceanography}

Winds in 1990 were weak compared with those in 1991. In 1990 from mid April to June, when pollock larvae were abundant in the water column, winds exceeded $10 \mathrm{~m} \mathrm{~s}^{-1}\left(1000 \mathrm{~m}^{3} \mathrm{~s}^{-3}\right)$ on only 1 occasion in late May (Fig. 2; winds are shown as wind speed cubed, an index of turbulence which is presumed to be the major factor affecting larval feeding). By contrast, in 1991 during the roughly 2 wk period in late April to early May winds were vigorous, exceeding 

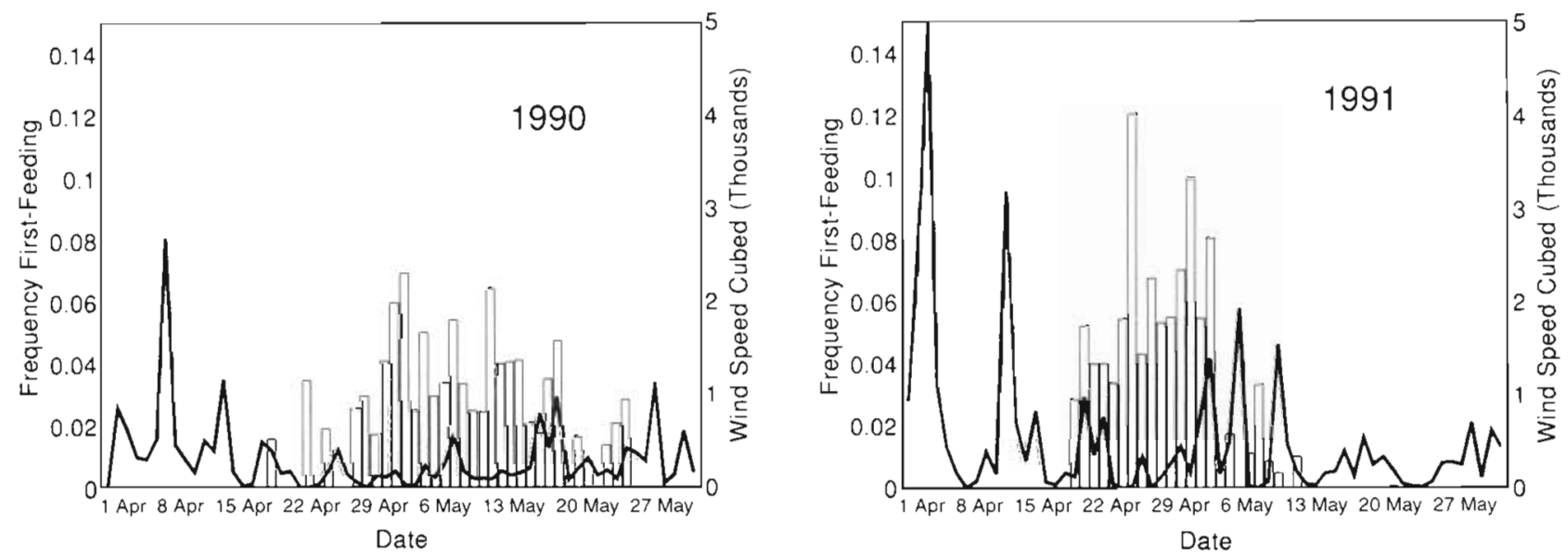

Fig. 2. Geotriptic wind speed $\left(\mathrm{m} \mathrm{s}^{-1}\right.$ ) (lines) cubed calculated from atmospheric pressure gradients near exit region of Shelikof Strait, and hatch date distributions (bars) of walleye pollock Theragra chalcogramma larvae, lagged forward $5 \mathrm{~d}$ to the firstfeeding period, that survived to be sampled in the late May surveys

$10 \mathrm{~m} \mathrm{~s}^{-1}$ on 3 occasions. Also shown in Fig. 2 is the first-feeding date distribution of larvae that survived to be sampled in the late May cruises. In 1991 few larvae survived to be sampled in late May from the expected peak in first-feeding abundance, around the first week in May, Most surviving larvae from 1991 attained first-feeding readiness during a lull in the winds in mid to late April.
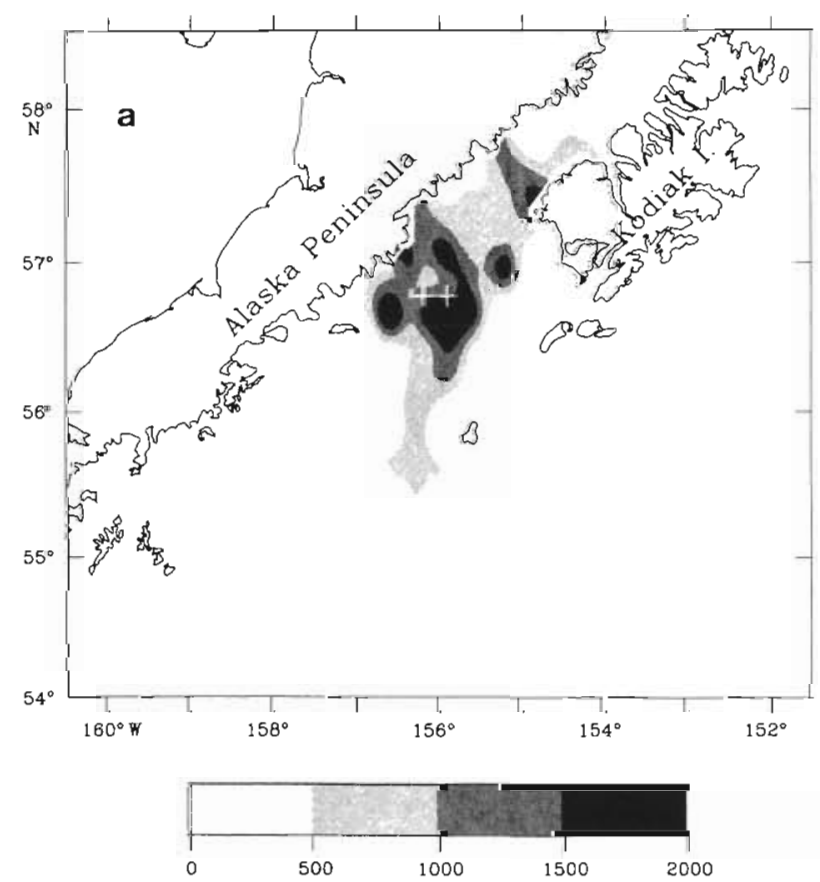

Mean sea surface temperatures for 1990 in the Shelikof-Shumagin area were $3.66^{\circ} \mathrm{C}$ and $5.47^{\circ} \mathrm{C}$ for April and May, respectively, and for 1991 were $3.44^{\circ} \mathrm{C}$ and $4.87^{\circ} \mathrm{C}$. In 1990 the mean mixed layer depth was $14 \mathrm{~m}(\mathrm{n}=7)$, while in 1991 the mean mixed layer depth was $68 \mathrm{~m}(\mathrm{n}=9)$. Three satellite-tracked drifters released in 1990 showed little displacement and were entrained in an eddy in the exit region of Shelikof

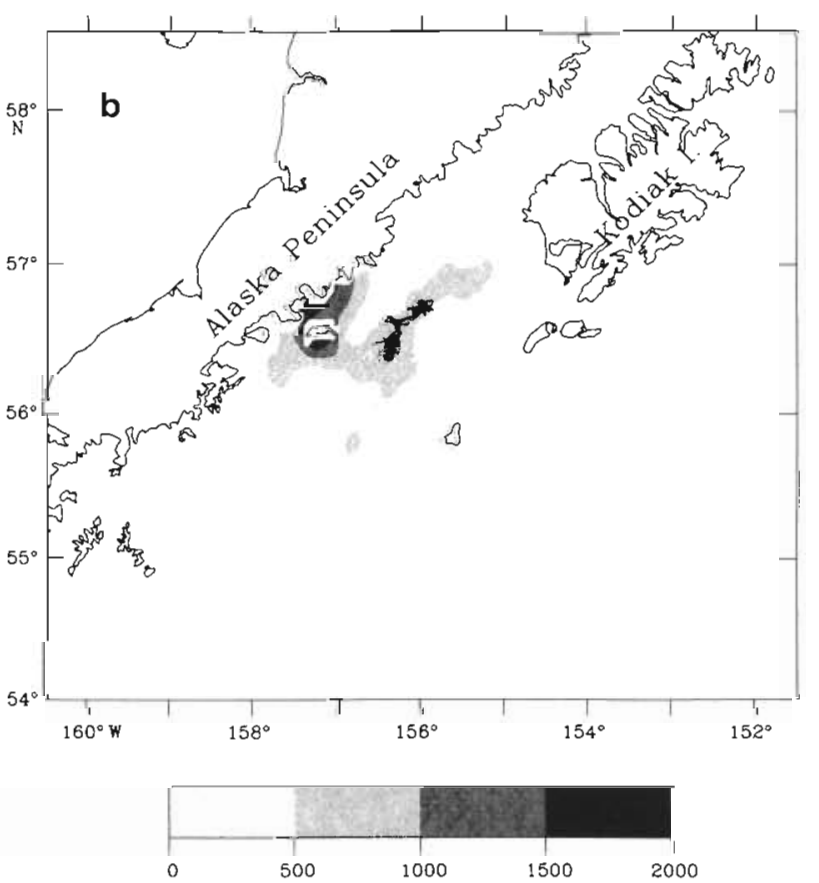

Fig. 3. Theragra chalcogramma. (a) Distribution of walleye pollock larvae during early May 1990; $(+)$ release sites of satellitetracked drifters drogued at $40 \mathrm{~m}$ depth. (b) Distribution of walleye pollock larvae during late May 1990; (-) drifter tracks from release to the end of the survey period. Units in catch $10 \mathrm{~m}^{-2}$ 

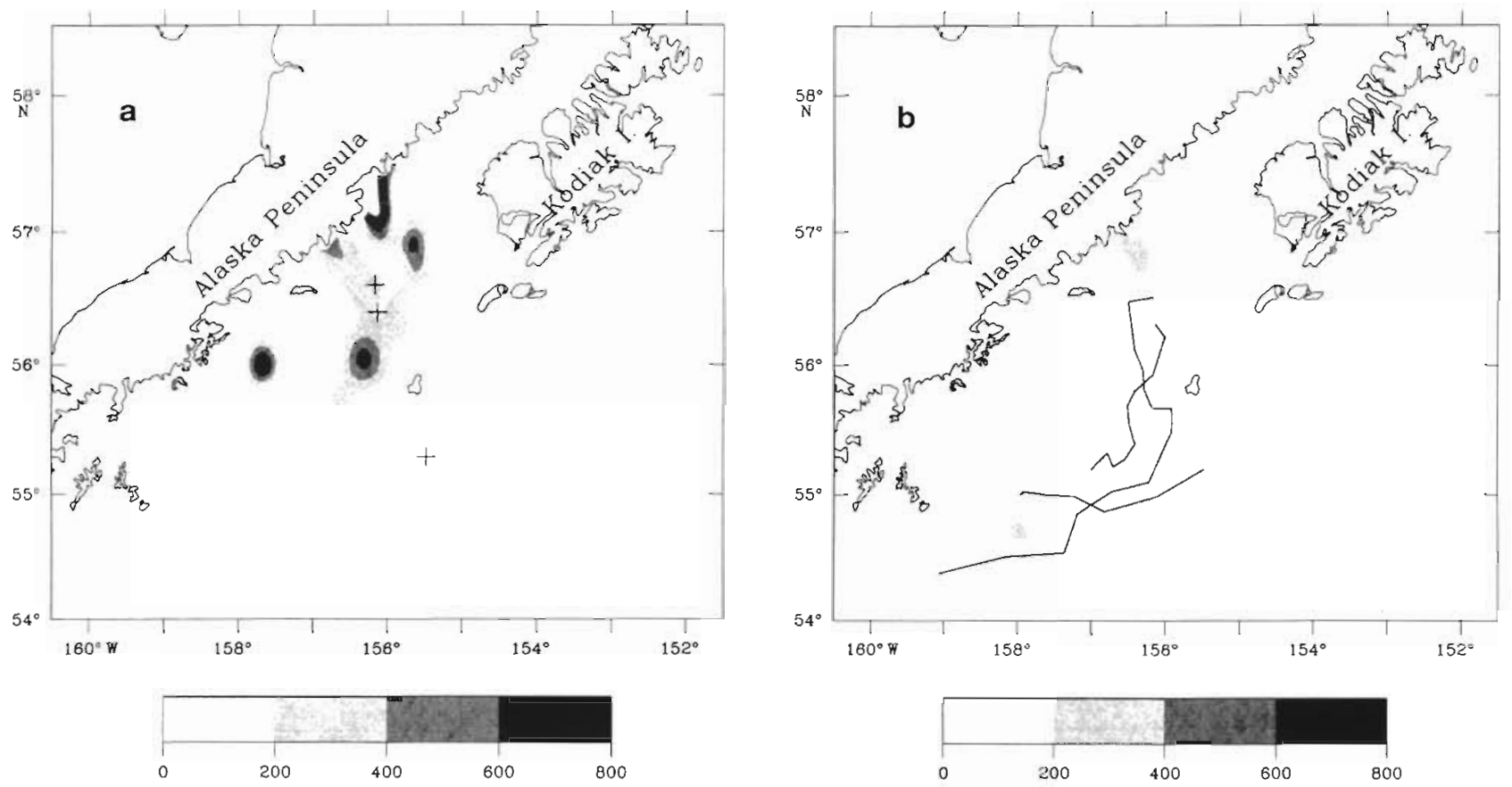

Fig. 4. Theragra chalcogramma. (a) Distribution of walleye pollock larvae during early May 1991; (+) release sites of satellitetracked drifters drogued at $40 \mathrm{~m}$ depth. (b) Distribution of walleye pollock larvae during late May 1991; (-) drifter tracks from release to the end of the survey period. Units in catch $10 \mathrm{~m}^{-2}$

Strait (Fig. 3). In 1991, drifters were not entrained in eddies and flow through the region was vigorous (Fig. 4).

\section{Larval distributions}

In 1990 larvae were concentrated in several main aggregations (Fig. 3a); at least 1 of the aggregations coincided with an eddy. Movement of drifters and aggregations between cruises indicated that the main aggregations of larvae were effectively resampled on the late May cruise (Fig. 3b).

In 1991 larvae were less abundant and more dispersed (Fig. 4a, b; note difference in scales between years). Movement of satellite-tracked drifters deployed in the area indicated that some advection of larvae out of the survey region was probable.

\section{Microzooplankton}

In early May 1990, the abundance of potential prey items (copepod nauplii and eggs) was among the highest sampled during this calendar period for the years 1985 to 1991 ( $\mathrm{J}$. Napp unpubl. data). Integrated numbers of nauplii exceeded $1 \times 10^{6} \mathrm{~m}^{-2}$ (median $25 \mathrm{l}^{-1} ; \mathrm{n}=11$ ) at all sampled stations and the median proportion of eggs to nauplii was 0.51 suggesting a large 'reservoir' of both present and future prey items.

Comparing stations inside and outside the eddy in early May 1990, naupliar biovolume, which weights concentration by size (volume), was lower inside the eddy region (Stns 13 and 14) than outside and immediately upstream (Stns 11 and 12), and was more comparable to a station much further downstream, near the mouth of the sea valley (Stn 19; Table 2). Vertical stratification of potential prey items (nauplii and eggs) also appeared to be less inside the eddy than outside (Fig. 5).

In early May 1991, the abundance of potential prey items was among the lowest we have sampled (1985 to 1991) during this calendar period. Integrated numbers of nauplii were less than $0.8 \times 10^{-6} \mathrm{~m}^{-2}$ (the median was only $4.81^{-1} ; n=12$ ) at all stations (Table 2 ). The median proportion of eggs to nauplii was 0.80 .

More extensive geographic sampling was conducted in 1991, including: 2 inshore stations, 4 sea valley stations, 3 offshore stations, and 3 sea valley stations occupied while following a buoy (Table 2). The time between sampling the first and last stations in this comparison was ca $10 \mathrm{~d}$. The hypothesis that prey availability was the same in all 4 regions/operations was rejected for both integrated naupliar biovolume and integrated total nauplii (ANOVA, $p=0.046$, $p=0.049$, respectively). Integrated biovolume of cope- 
pod nauplii (prey) was highest inside the patch marked with the buoy and lowest nearshore. However biomass everywhere was low relative to 1990.

Where chl a was measured, changes in integrated invertebrate eggs, nauplii $<150 \mu \mathrm{m}$ and nauplii $\geq 150 \mu \mathrm{m}$ (no. $\mathrm{m}^{-2}$ ) were concordant with changes in integrated chlorophyll $\left[\mu \mathrm{g} \mathrm{m}^{-2} ; \mathrm{p}<0.01\right.$, Kendall's Test for Concordance (Tate \& Clelland 1957)]. Thus over this small range of very low prey concentrations, the higher the standing stock of phytoplankton, the more prey for the pollock larvae.

\section{Feeding, nutritional condition and growth}

Larval length had a significant effect on the number of prey per gut in both 1990 and 1991 ( $p=0.019$ and $p=0.047$, respectively). Within-year ANCOVA tests of the number of prey per gut versus area with length as a covariate indicated no significant differences in feeding intensity among areas. Feeding intensity differed between years; there were about 2 times more prey per larval gut in 1990 compared with 1991 (Fig. 6; p < $0.001)$. For example, in 1990 a mean of 9 prey gut $^{-1}$ for a $7 \mathrm{~mm}$ larva was estimated while a value for a $7 \mathrm{~mm}$ larva in 1991 would be about 4 prey gut ${ }^{-1}$.

Using pooled samples from 1990, the effect of time of day (06:00 to $22: 00 \mathrm{~h}$, day; 22:00 to 06:00 h, night) on RNA content was examined by ANCOVA with time of day as a categorical variate and SL as the covariate. There was no significant diel effect $(\mathrm{p}=0.408, \mathrm{n}=87$ ). Night stations in 1991 were too few for comparison. In 1990, no significant differences in RNA content were noted among areas (ANCOVA, $p=0.937, n=87$ ). In 1991, comparison among areas indicated that larvae in the offshore area had significantly lower RNA content compared with the other areas $(p=0.001, n=120)$. No other differences among areas were noted. For between-year comparisons, the 2 offshore stations with significant within-year differences were dropped from the analysis and annual data were pooled. Highly significant differences were observed between years
Fig. 5. Vertical distribution of copepod eggs and nauplii in early May 1990 at representative stations (A) upstream from eddy, (B) immediately upstream from the eddy, (C) in the eddy region, (D) downstream from the eddy near the mouth of the sea valley
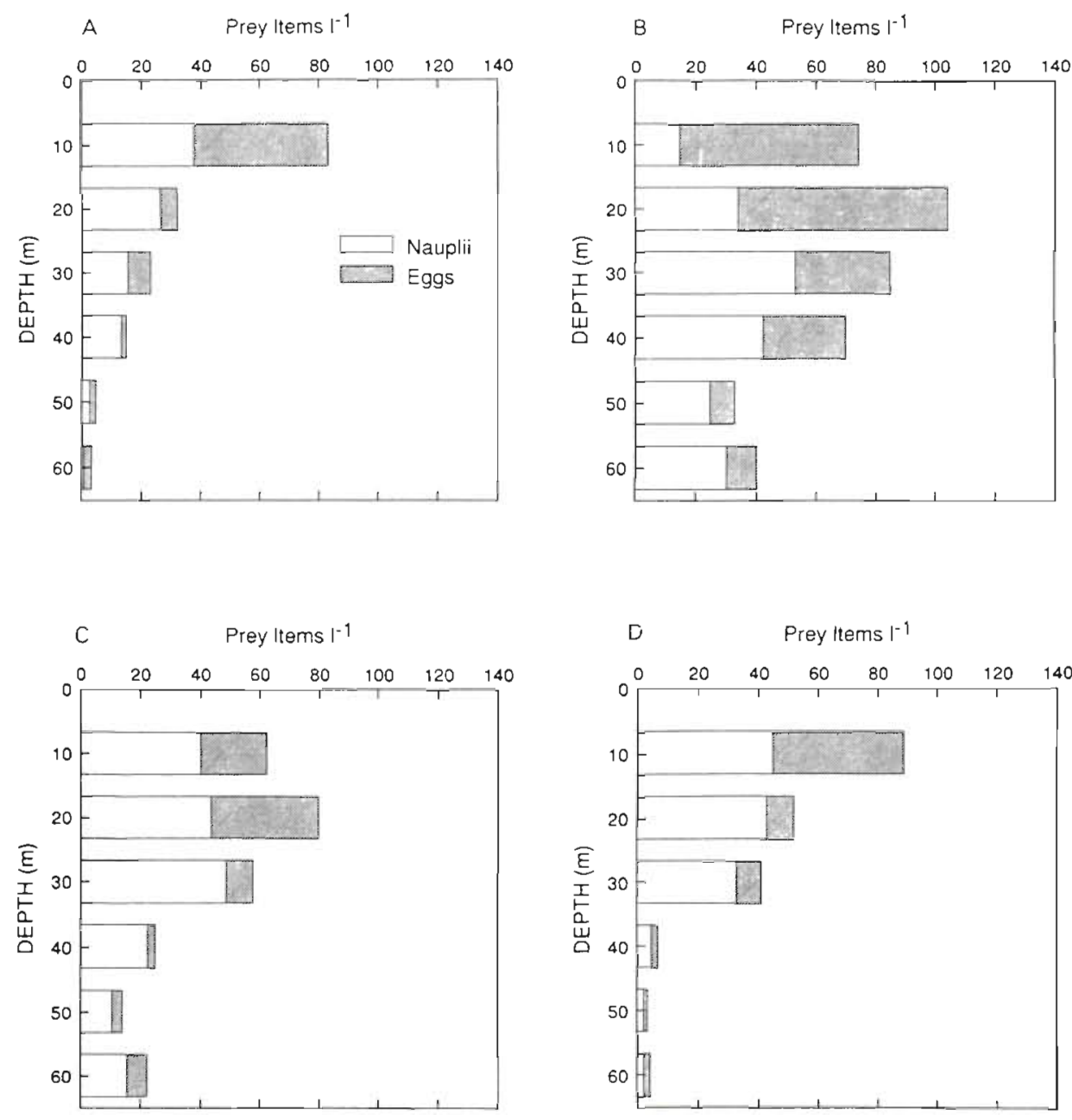


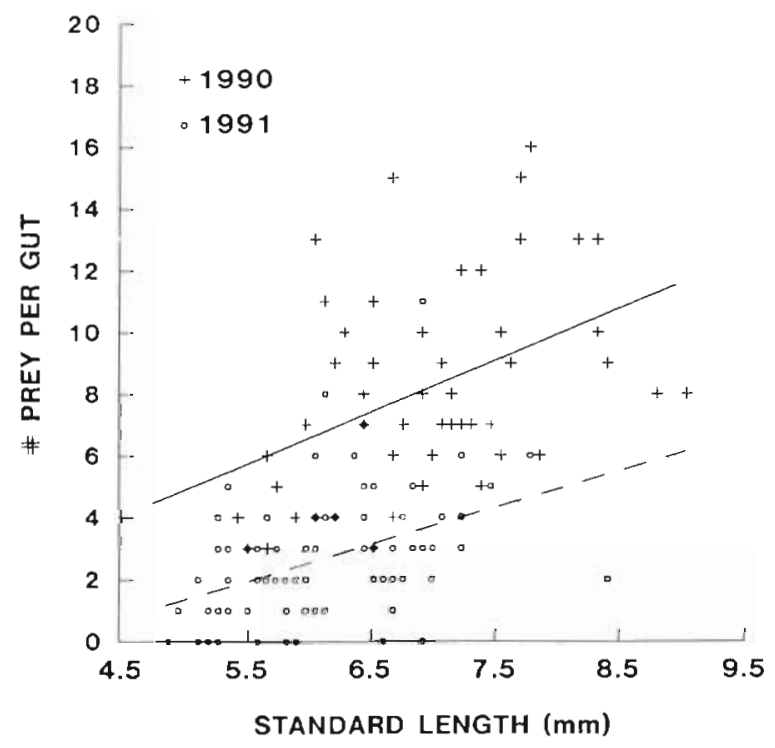

Fig. 6. Theragra chalcogramma. Comparison of number of prey per larval gut against standard larval length for early May $1990(+)$ and 1991 (ㄷ). Linear regression equations for $1990(-)$ and $1991(---)$ are shown

$(\mathrm{p}=0.001, \mathrm{n}=192) ;$ in 1991, RNA content was low for a given larval length compared with 1990 (Fig. 7).

Differences in length-at-age were examined by ANOVA and ANCOVA. In 1990 stations in the eddy, offshore and inshore areas were separated by cruise.

Table 2. Prey availability for 1990 and 1991. Average abundance and integrated biovolume of copepod nauplii (0 to $60 \mathrm{~m}$ ). Stations are ordered from northeast to southwest along Shelikof Strait.

\begin{tabular}{|clcc|}
\hline Cast no. & Location & $\begin{array}{c}\text { Average abundance } \\
\left(\text { no. } \mathrm{I}^{-1}\right)\end{array}$ & $\begin{array}{c}\text { Integrated biovolume } \\
\left(\times 10^{12} \mu \mathrm{m}^{3} \mathrm{~m}^{-2}\right)\end{array}$ \\
\hline $\mathbf{1 9 9 0}$ & & & \\
22 & Shelikof entrance & 34 & 4.95 \\
9 & Upstream & 19 & 2.56 \\
12 & Upstream, near eddy area & 32 & 5.20 \\
11 & Vicinity of eddy & 37 & 4.28 \\
13 & Eddy area & 32 & 3.38 \\
14 & Downstream, near eddy & 25 & 3.07 \\
19 & Offshore & 22 & 3.04 \\
$\mathbf{1 9 9 1}$ & & & \\
27 & Nearshore & 1 & 0.05 \\
28 & Nearshore & 3 & 0.23 \\
15 & Sea valley & 5 & 0.37 \\
25 & Sea valley & 3 & 0.40 \\
26 & Sea valley & 2 & 0.26 \\
29 & Sea valley & 5 & 0.57 \\
51 & Sea valley & 13 & 0.68 \\
53 & Sea valley & 12 & 0.72 \\
54 & Sea valley & 9 & 0.75 \\
18 & Offshore & 7 & 0.59 \\
19 & Offshore & 2 & 0.14 \\
30 & Offshore & 6 & 0.51 \\
& & & \\
\hline
\end{tabular}

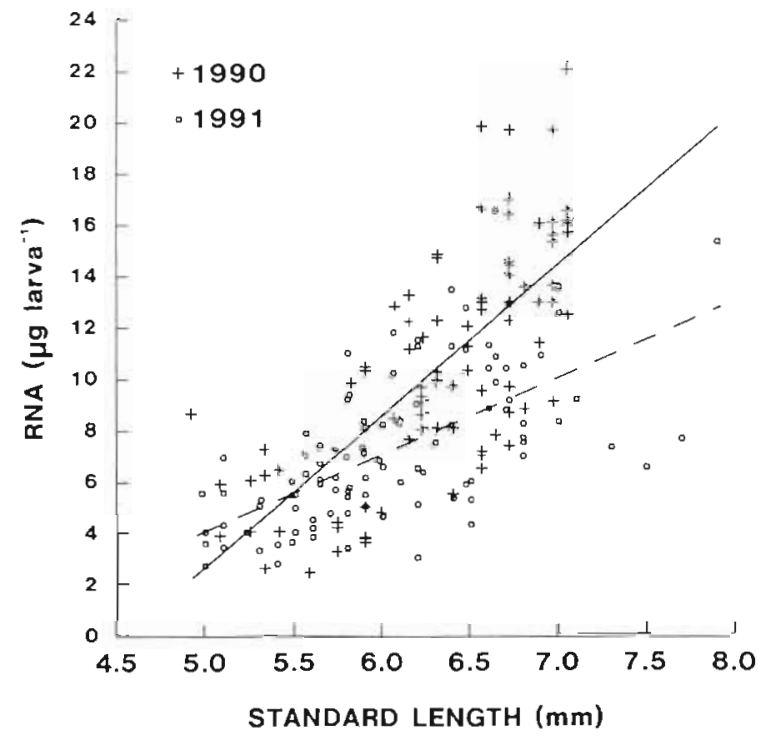

Fig. 7. Theragra chalcogramma. Comparison of RNA content of larvae against standard length for early May $1990(+)$ and 1991 (). Linear regression equations for 1990 ( - ) and 1991 $(--)$ are shown

Differences in slopes were not detected in comparisons of within-eddy stations, inshore and offshore stations $(p>0.05)$. In 1991 there were differences between inshore stations and most stations over the sea valley in early May $(p<0.05)$ and in offshore stations and the rest of the stations in late May $(p<0.05)$.

Length-at-age was compared between pooled 1990 and 1991 samples (excluding the offshore stations sampled in late May 1991 since their length-at-age was significantly low). The slopes of length regressed on age were significantly different between 1990 and 1991 ( $p=0.002$ ), with 1991 length-at-age lower than 1990 (Fig. 8). The slope of the 1991 regression was higher, and appears to converge with 1990 lengths at about $40 \mathrm{~d}$, probably reflecting the loss of smaller lengthat-age fish from the 1991 population.

\section{Mortality}

Mortality rates were compared for cohorts of early feeding larvae sampled in early May and late May in both years (Table 3). Mortality of the early feeding larvae in 1990 was less than half that of larvae in 1991 (0.107 versus 
Table 3. Mortality rates for cohorts of walleye pollock larvae sampled from 2 sequential cruises in 1990 and $1991 . t_{1}$ : initial time of sampling; $t_{2}$ : second sampling

\begin{tabular}{|ccccccc|}
\hline Year & $\begin{array}{c}\text { Hatch date } \\
\text { (day of the year) }\end{array}$ & $\begin{array}{c}\text { Age at } \\
t_{1}(\mathrm{~d})\end{array}$ & $\begin{array}{c}\text { Abundance at } \\
t_{1}(\mathrm{SD})\end{array}$ & $\begin{array}{c}\text { Age at } \\
t_{2}(\mathrm{~d})\end{array}$ & $\begin{array}{c}\text { Abundance at } \\
t_{2} \text { (SD) }\end{array}$ & $\begin{array}{c}\text { Mortality } \\
\left(\mathrm{d}^{-1}\right)(\mathrm{SD})\end{array}$ \\
\hline 1990 & 118 & 12 & $2.92 \times 10^{11}\left(5.49 \times 10^{10}\right)$ & 34 & $1.25 \times 10^{11}\left(1.62 \times 10^{10}\right)$ & $0.038(0.010)$ \\
& 121 & 9 & $4.44 \times 10^{11}\left(7.97 \times 10^{10}\right)$ & 31 & $8.72 \times 10^{10}\left(1.20 \times 10^{10}\right)$ & $0.074(0.010)$ \\
& 124 & 6 & $8.73 \times 10^{11}\left(1.15 \times 10^{11}\right)$ & 28 & $8.22 \times 10^{10}\left(1.10 \times 10^{10}\right)$ & $0.107(0.009)$ \\
1991 & 114 & 12 & $8.96 \times 10^{9}\left(4.82 \times 10^{9}\right)$ & 28 & $3.75 \times 10^{9}\left(2.40 \times 10^{9}\right)$ & $0.054(0.052)$ \\
& 117 & 9 & $8.78 \times 10^{10}\left(2.29 \times 10^{10}\right)$ & 25 & $1.51 \times 10^{10}\left(3.97 \times 10^{9}\right)$ & $0.110(0.023)$ \\
& 120 & 6 & $3.18 \times 10^{11}\left(7.22 \times 10^{10}\right)$ & 22 & $1.05 \times 10^{10}\left(4.08 \times 10^{9}\right)$ & $0.213(0.028)$ \\
\hline
\end{tabular}

$0.213 \mathrm{~d}^{-1}$, respectively). Mortality estimates in 1990 probably did not include a significant loss from the grid region as evidenced by retention of the drifters. However, in 1991 mortality likely included some loss of larvae from the sampling region, as 1 of 3 drifters moved out of the exit region of Shelikof Strait and into the Alaska Stream.

\section{DISCUSSION}

Shelikof Strait is a dynamic oceanographic regime and is in an area frequented by storms (Wilson \& Overland 1986). Flow through the strait is influenced by both baroclinic and barotropic forces (Royer 1981, Reed \& Schumacher 1989). The 2 years of this study represented marked contrasts in oceanographic condi-



Fig. 8. Theragra chalcogramma. Comparison of standard length against otolith-determined age for larvae sampled in early and late May, $1990(+)$ and 1991 (o). Linear regression equations for $1990(-)$ and $1991(---)$ tions: 1990 was characterized by relatively calm winds, warmer water temperatures, weak advection through the sea valley and formation of at least 1 major eddy, while 1991 was characterized by vigorous winds, cooler water temperatures and strong advection through the sea valley. A 2 wk period of storms overlapping with the early larval feeding stage, such as observed in early May 1991, can have a catastrophic effect on recruitment to the Shelikof Strait pollock population because $90 \%$ of the larvae produced are spawned in a period of $3 \mathrm{wk}$ or less and attain early feeding stage in late April to early May. Bailey \& Macklin (1994) have shown the negative effect of storminess on survival of first-feeding pollock larvae in a statistical time series analysis

Oceanographic differences between the 2 years cascaded through the food chain, as reflected in the measured concentrations of copepod nauplii, and in the feeding success, condition, growth and mortality of walleye pollock larvae. In 1990 the median naupliar concentration was about 5 times greater and naupliar biovolume was 7 times greater compared with 1991. Likewise, the number of prey per gut, larval RNA content and length-at-age were increased in $1990 \mathrm{com}-$ pared with 1991, indicating that higher prey levels translated into better nutritional condition and growth. Therefore, 1990 was a year when food was sufficient for relatively high larval growth and 1991 represented a year when food was limiting.

It is thought that Shelikof Strait normally experiences a spring phytoplankton bloom typical of temperate coastal regions; primary production is initially limited by light until the critical depth exceeds the mixed layer depth (Sverdrup 1953). Phytoplankton population growth then exceeds losses such that standing stock rapidly increases until a combination of nutrient limitation, grazing and sinking remove more cells than are being produced and standing stock declines. However the details of this process (e.g. timing, magnitude, and duration) are conspicuously lacking for this region (Sambrotto \& Lorenzen 1986). 
In 1991, we observed low chlorophyll concentrations (median $1.52 \mu \mathrm{g}^{-1}, \mathrm{n}=47$, casts $=9$ ) as well as deeper mixed layer depths than in 1990. The low chlorophyll concentrations for this time of year may have been the result of lower production rates due to vigorous wind mixing (below the critical depth) relative to incident solar radiation, however we cannot eliminate the possibility of high grazing pressure. Nitrogenous nutrient concentrations were sufficient to maintain maximal phytoplankton growth rates.

Transfer of energy from the phytoplankton to the fish larvae involves at least 1 intermediate step: production of copepod eggs and nauplii (although some carbon for egg production may come from ingestion of protozod; e.g. Stoecker \& Capuzzo 1990, Ohman et al. 1991). At the low chlorophyll concentrations measured $(<80 \mu \mathrm{g}$ carbon $\mathrm{l}^{-1}$ for carbon: chlorophyll $=50$ ) egg production by Pseudocalanus spp. females was probably food limited. Pseudocalanus mimus females, a major prey producer for pollock larvae (Siefert 1994), require greater than $100 \mu \mathrm{g} \mathrm{Cl}^{-1}$ for maximum egg production rates at these temperatures (J. Napp unpubl. data). Other nauplii prey for larval pollock in Shelikof Strait are most likely produced by Metridia spp. and Calanus spp. (Kendall et al. 1987, Incze \& Ainaire 1994). Compared with Pseudocalanus spp., Calanus spp. and Metridia spp. require large amounts of food to reach their maximal reproductive rates. Because chlorophyll levels were low, water temperatures were relatively cold, and nauplii were sparse in 1991, it appears that the narrow time interval over which first-feeding pollock larvae appear in the surface waters requiring food probably preceded the annual spring bloom. This condition created a temporal mismatch between predators and prey (Cushing 1972).

The relatively small length-at-age of feeding stage larvae in 1991 compared with 1990 (Fig. 8) could be due to low temperatures observed in 1991 and consequent slower growth through the yolk sac stage. Larvae may also have been distributed deeper in the water column and subject to more shrinkage during capture (Theilacker \& Porter in press). However, the lower feeding indices (Fig. 6) and RNA content (Fig. 7) support the contention that larvae were growing more slowly in 1991 due to poor feeding conditions (Table 2).

In 1990, mortality rates of early feeding larvae were about $0.11 \mathrm{~d}^{-1}$ compared with $0.21 \mathrm{~d}^{-1}$ in 1991 . In 1990 , the movement of satellite-tracked drifters combined with shifting of the survey region downstream leads us to believe that there was little advection of larvae out of the survey region. Based on runs of a model of advection and diffusion for the Shelikof Strait region, the diffusion component of dispersal from large-scale grids, very similar to those occupied in 1990 and 1991, probably accounts for a loss of walleye pollock larvae less than $0.5 \% \mathrm{~d}^{-1}$ (Hinckley et al. 1993). This is concordant with Hill's (1991) findings that if advective loss was zero (or completely accounted for), moderate eddy diffusion coefficients $\left(K_{\mathrm{H}}=\mathrm{ca} 200 \mathrm{~m}^{2} \mathrm{~s}^{-1}\right)$ would account for losses of about $0.7 \% \mathrm{~d}^{-1}$. These losses are small compared with our mortality coefficients. Furthermore, Hinckley et al. (1993) observed that in their models of advection and diffusion, the patch structure of the larval distribution was lost after a few days, even with very low eddy diffusion coefficients $\left(K_{\mathrm{f}}=50 \mathrm{~m}^{2}\right.$ $\left.\mathrm{s}^{-1}\right)$. These results indicate the possibility that unknown retention features are operating and that $K_{\mathrm{H}}$ is not constant throughout the region. Hill (1991) noted that advective losses are likely to be the most important consideration in larval retention. Although we attempted to account for advection by shifting the grid downstream in proportion to drifter displacement, in 1991 there was very vigorous flow out of the survey region and even though the second survey was shifted downstream, it seems likely that some larvae were swept out of the survey region and entrained in the Alaskan Stream. Thus, advection probably contributed to the apparent high mortality rate in 1991. Although these larvae could have re-entered the shelf farther downstream, larvae in the offshore region showed evidence of poor nutritional condition and growth, and therefore we postulate that they expired, or that once expatriated (Sinclair 1988), they would contribute little to recruitment of the 1991 Shelikof Strait year class. This contention is supported by data from an extensive juvenile survey conducted in late July 1991 showing the walleye pollock age 0 juveniles were unusually sparse along the Aleutian Peninsula and eastern Aleutian Islands (R. D. Brodeur, M. S. Busby \& M. T. Wilson unpubl.).

Some portion of the lower larval abundance in 1991 compared with 1990 could have been due to higher egg mortality. In 1990 egg production was estimated at $0.94 \times 10^{14}$ and seasonal egg mortality was $0.148 \mathrm{~d}^{-1}$ while in 1991 egg production was $1.56 \times 10^{14}$ and egg mortality was $0.222 \mathrm{~d}^{-1}$ (S. Picquelle, Alaska Fisheries Science Center, pers. comm.). Corresponding numbers of larvae hatched would be $0.12 \times 10^{14}$ and $0.07 \times 10^{14}$ in 1990 and 1991, respectively, a difference of 1.7 -fold. However, a sizable portion of the egg mortality may include an advective dispersal component since the grids were stationary between surveys and did not account for displacement. Furthermore, compared with the 1.7 -fold difference in estimated number of hatched larvae between years, the difference in total larval abundance among years during the early May cruises was 4.2 -fold $\left(1.75 \times 10^{12}\right.$ larvae in 1990 and $4.15 \times 10^{11}$ larvae in 1991).

The strong winds and turbulence associated with the storminess of 1991 could have enhanced contact rates 
between larvae and their prey (Sundby \& Fossum 1990). However, the marked differences between nominal prey densities in 1990 and 1991 appears to have overwhelmed any effect of enhanced contact rates, as reflected by the differences in larval gut contents and nutritional condition.

Eddies are prominant features in Shelikof Strait (Mysak et al. 1981, Bograd et al. 1994), although locating them in real time is governed by serendipity since persistent cloud cover hinders many remote sensing instruments (e.g. Advanced Very High Resolution Radiometer, AVHRR). In 1990 we were fortunate to locate an eddy and sample in it. There were no observed differences in feeding or nutritional condition inside and outside the 1990 eddy region. In 1990, prey abundances were relatively high throughout the survey region. Although there was not an apparent nutritional advantage to larvae residing in the eddy, the eddy may have had a retention effect, keeping larvae from being advected into the Alaska Stream. The eddy was relatively stationary for several weeks in the area and disintegrated as it entered the shoaling waters of the shelf (Schumacher et al. 1993). These observations differ from those in 1989, where larvae sampled in late April from an aggregation (this aggregation was later discovered to coincide with an eddy; Bograd et al. 1994) were residing in higher nauplii densities and were in better nutritional condition compared with surrounding waters. However, later in 1989, after the copepod production cycle had matured, naupliar densities were high and larvae were in good nutritional condition throughout the region.

In 1991, naupliar biomass levels were variable in the different regions. Naupliar biovolume was especially low in the 2 nearshore stations and was relatively higher, but still low, in the offshore stations. Larvae were not observed to be in poor condition in the nearshore stations, but were in poor condition (low RNA content and growth rates) in the offshore stations. Since the movement of satellite-tracked drifters and patterns in larval distribution indicated a strong flow through the sea valley, many larvae were swept offshore and entrained in the Alaska Stream, where conditions appeared to be poor for survival.

Mullin (1993) indicated that ideally, if larval feeding was crucial, then prey abundance would translate into higher growth and lower mortality, and eventually to better recruitment. In spite of the much better feeding conditions and higher survival observed in 1990, both the 1990 and 1991 year classes appear to be relatively weak (Anne Hollowed, Alaska Fisheries Science Center, pers. comm.). The 1988 year class of pollock has dominated the population in recent years; this year class also had the lowest larval mortality rate $(m=0.04$ $\mathrm{d}^{-1}$ ) over our period of observation (K. Bailey unpubl. data). Thus relatively low larval mortality can lead to formation of a strong year class, but events in late larval and early juvenile stages also can affect the relative strength of recruitment to the fishery (Wooster \& Bailey 1989, Bailey \& Spring 1992). In Shelikof Strait, low larval mortality is a necessary, but not always sufficient condition for recruitment success of a year class.

In conclusion, prey densities for larval walleye pollock vary seasonally, geographically and interannually, and are not saturating the feeding capabilities and growth requirements of larvae in all circumstances. In particular, interannual variability in prey abundance at the time when most larvae are ready to feed appears to be an important component in larval mortality rates.

Acknowledgements. We thank Kathy Mier for performing the power analysis, Lisa Brit for providing the microzooplankton data and preliminary analyses, Debbie Siefert, Jay Clark and other members of the FOCI group for their efforts at sea and in the laboratory, and S. Picquelle for her advice and consultation on statistics throughout this study. We also thank A.W. Kendall, L. Haldorson, and G. Theilacker for comments on a draft of the manuscript. This is FOCI contribution no. 214.

\section{LITERATURE CITED}

Bailey, K. M., Macklin, S. A. (1994). Analysis of patterns in larval walleye pollock Theragra chalcogramma survival and wind mixing events in Shelikof Strait, Gulf of Alaska Mar. Ecol. Prog. Ser. 113: 1-12

Bailey, K. M., Spring, S. M. (1992). Comparison of larval, age0 juvenile and age- 2 recruit abundance indices of walleye pollock, Theragra chalcogramma, in the western Gulf of Alaska. ICES J. mar. Sci. 49: 297-304

Bailey, K. M., Stehr, C. L. (1988). The effects of feeding periodicity and ration on the rate of increment formation in otoliths of larval walleye pollock Theragra chalcogramma (Pallas). J. exp. mar. Biol. Ecol. 122: 147-161

Bentle, L., Dutta, S., Metcoff, J. (1981). The sequential enzymatic determination of DNA and RNA. Analyt. Biochem. 116: 5-16

Bograd, S. J., Stabeno, P. J., Schumacher, J. D. (1994). A census of meoscale eddies on a continental shelf: Shelikof Strait, Alaska. J. geophys. Res. 99: 18243-18254

Bollens, S. M., Frost, B. W., Schwaninger, H. R., Davis, C. S., Way, K. J., Landsteiner, M. C. (1992). Seasonal plankton cycles in a temperate fjord and comments on the matchmismatch hypothesis. J. Plankton Res. 14: 1279-1305

Brown, A. L., Bailey, K. M. (1992). Otolith analysis of juvenile walleye pollock Theragra chalcogramma from the western Gulf of Alaska. Mar. Biol. 112: 23-30

Buckley, L. J. (1980). Changes in ribonucleic acid, deoxyribonuclejc acid, and protein content during ontogenesis in winter flounder, Pseudopleuronectes americanus, and effect of starvation. Fish. Bull. U.S. 77: 703-708

Buckley, L. J. (1981). Biochemical changes during ontogenesis of cod (Gadus morhua L.) and winter flounder (Pseudopleuronectes americanus) larvae. Rapp. P.-v. Réun. Cons. int. Explor. Mer 178: 547-552

Buckley, L. J., Lough, R. G. (1987). Recent growth, biochemical composition, and prey field of larval haddock (Melanogrammus aeglefinus) and Atlantic cod (Gadus 
morhua) on Georges Bank. Can. J. Fish. Aquat. Sci. 44: $14-25$

Canino, M. F. (1994). Effects of temperature and food availability on growth and RNA/DNA ratios of walleye pollock Theragra chalcogramma (Pallas) eggs and larvae. J. exp. mar. Biol. Ecol. 125: 1-16

Canino, M. F., Bailey, K. M. (in press). Gastric evacuation of walleye pollock, Theragra chalcogramma (Pallas), larvae in response to feeding conditions. J. Fish. Biol.

Canino, M. F., Bailey, K. M., Incze, L. S. (1991). Temporal and geographic differences in feeding and nutritional condition of walleye pollock larvae Theragra chalcogramma in Shelikof Strait, Gulf of Alaska. Mar. Ecol. Prog. Ser. 79: $27-35$

Cohen, R. E., Lough, R. G. (1983). Prey field of larval herring Clupea harengus on a continental shelf spawning area. Mar. Ecol. Prog. Ser. 10: 211-222

Coombs, S. H., Nichols, J. H., Conway, D. V. P., Milligan, S., Halliday, N. C. (1992). Food availability for sprat larvae in the Irish Sea. J. mar. biol. Ass. U.K. 72: 821-834

Cushing, D. H. (1972). The production cyle and numbers of marine fish. In: Edwards, R. W., Garrod, D. J (eds.) Conservation and productivity of natural waters. Symp. zool. Soc. Lond. 29: 213-232

Fortier, L., Gagne, J. A. (1990). Larval herring (Clupea harengus) dispersion, growth, and survival in the St. Lawrence Estuary: match/mismatch or membership/vagrancy? Can. J. Fish. Aquat. Sci. 47: 1898-1912

Fossum, P., Moksness, E. (1993). A study of spring- and autumn-spawned herring (Clupea harengus) larvae in the Norwegian Coastal Current during spring 1990. Fish. Oceanogr. 2: 73-81

Gadomski, D. M., Boehlert, G. W. (1984). Feeding ecology of pelagic larvae of English sole Parophrys vetulus and butter sole Isopsetta isolepis off the Oregon coast. Mar. Ecol. Prog. Ser. 20: 1-12

Govoni, J. J., Chester, A. J., Hoss, D. E., Ortner, P. B. (1985) An observation of episodic feeding and growth of larval Leiostomus xanthurus in the northern Gulf of Mexico. J. Plankton Res. 7: 137-146

Haldorson, L., Paul, A. J., Sterritt, D., Watts, J. (1989). Annual and seasonal variation in growth of larval walleye pollock and flathead sole in a southeastern Alaskan bay. Rapp P.-v. Réun. Cons. int. Explor. Mer 191: 220-225

Heath, M. (1989). A modelling and field study of grazing by herring larvae. Rapp. P.-v. Réun. Cons. int. Explor. Mer 191: $233-247$

Hill, A. E. (1991). Advection-ciffusion-mortality solutions for investigating pelagic larval dispersal. Mar. Ecol. Prog. Ser. 70: $117-128$

Hinckley, S., Bailey, K. M., Picquelle, S, Schumacher, J., Stabeno, P. (1991). Transport, distribution, and abundance of larval and juvenile walleye pollock (Theragra chalcogramma) in the western Gulf of Alaska. Can. J. Fish. Aquat. Sci. 48: 91-98

Hinckley, S., Bailey, K. M., Picquelle, S., Yoklavich, M., Stabeno, P. (1993). Age-specific mortality and transport of larval walleye pollock (Theragra chalcogramma) in the western Gulf of Alaska. Mar. Ecol. Prog. Ser. 98: 17-29

Incze, L. S., Ainaire, T (1994). Distribution and abundance of copepod nauplii and other small $(40-300$ micron) zooplankton during spring in Shelikof Strait, Alaska. Fish. Bull. U.S. 92: $67-78$

Kendall, A. W. Jr, Clarke, M. E., Yoklavich, M. M., Boehlert, G. W. (1987). Distribution, feeding, and growth of larval walleye pollock, Theragra chalcogramma, from Shelikof Strait, Gulf of Alaska. Fish. Bull. U.S. 85: 499-521
Kendall, A. W. Jr, Incze, L. S., Ortner, P. B., Cummings, S. R. Brown, P. K. (1994). The vertical distribution of eggs and larvae of walleye pollock (Theragra chalcogramma) in Shelikof Strait, Gulf of Alaska. Fish. Bull. U.S. 92: 540-554

Kendall, A. W. Jr, Picquelle, S. J. (1990). Egg and larval distributions of walleye pollock Theragra chalcogramma in Shelikof Strait, Gulf of Alaska. Fish. Bull. U.S. 88: 133-154

Kiørboe, T., Munk, P., Richardson, K., Christensen, V., Paulsen, H. (1988). Plankton dynamics and larval herring growth, drift and survival in a frontal area. Mar. Ecol. Prog. Ser. 44: 205-219

Lasker, R. (1975). Field criteria for survival of anchovy larvae: the relation between inshore chlorophyll maximum layers and successful first feeding. Fish. Bull. U.S. 73: 453-462

Maillet, G. L., Checkley, D. M. (1991). Storm-related variation in the growth rate of otoliths of larval Atlantic menhaden Brevoortia tyrannus; a time series analysis of biological and physical variables and implications for larva growth and mortality. Mar. Ecol. Prog. Ser. 79: 1-16

McGurk, M. D., Paul, A. J., Coyle, K. O., Ziemann, D. A., Haldorson, L. J. (1993). Relationships between prey concentration and growth, condition, and mortality of Pacific herring, Clupea harengus, larvae in an Alaskan subarctic embayment. Can. J. Fish. Aquat. Sci. 50: 163-180

Mullin, M. M. (1993). Webs and scales. University of Washington Press, Seattle, WA

Munk, P. (1993). Differential growth of larval sprat Sprattus sprattus across a tidal front in the eastern North Sea. Mar. Ecol. Prog. Ser. 99: 17-27

Mysak, L., Muench, R. D., Schumacher, J. D. (1981). Baroclinic instability in a downstream varying channel: Shelikof Strait, Alaska. J. phys. Oceanogr. 11: 950-969

Nishimura, A., Yamada, J. (1984). Age and growth of larval and juvenile walleye pollock, Theragra chalcogramma (Pallas), as determined by otolith daily growth increments. J. exp. mar. Biol. Ecol. 82: 191-205

Ohman, M. D., Theilacker, G., Kaupp, S. E. (1991). Immunochemical detection of predation on ciliate protists by the Northern Anchovy (Engraulis mordax). Biol. Bull. 181: $500-504$

Owen, R. W., Lo, N. C. H., Butler, J. L., Theilacker, G. H., Alvarino, A., Hunter, J. R., Watanabe, Y. (1989). Spawning and survival patterns of larval northern anchovy, Engraulis mordax, in contrasting environments - a siteintensive study. Fish. Bull. U.S. 87: 673-688

Posgay, J. A., Marak, R. R. (1980). The MARMAP bongo zooplankton samplers. J. NW Atl. Fish. Sci. 1: 91-99

Reed, R. K., Schumacher, J. D. (1989). Transport and physical properties in central Shelikof Strait, Alaska. Cont. Shelf Res. 9: 261-268

Rice, J. A., Crowder, L. B., Holey, M. E. (1987). Exploration of mechanisms regulating larval survival in Lake Michigan Bloater: a recruitment analysis based on characteristics of individual larvae. Trans. Am. Fish. Soc. 116: 703-718

Royer, T. C. (1981). Baroclinic transport in the Gulf of Alaska Part II. Freshwater driven coastal current. J. mar. Res. 39: $251-266$

Sambrotto, R. N., Lorenzen, C. J. (1986). Phytoplankton and primary production. In: Hood, D. W., Zimmerman, S. T (eds.) The Gulf of Alaska: physical environment and biological resources. Minerals Management Service Publ MMS 86-0095, Anchorage, AK, p. 249-284

Schumacher, J. D., Stabeno, P. J., Bograd, S. J. (1993). Characteristics of an eddy over a continental sheif: Shelikof Strait, Alaska. J. geophys. Res. 98: 8395-8404

Shelbourne, J. (1957). The feeding and condition of plaice larvae in good and bad plankton patches. J. mar. biol. Ass 


\section{U.K. 36: 539-552}

Shima, M., Bailey, K. M. (1994). Comparative analysis of ichthyoplankton sampling gear for early life stages of walleye pollock (Theragra chalcogramma). Fish. Oceanogr. 3 : $50-59$

Siefert, D. L. W. (1994). The importance of sampler mesh size when estimating total daily egg production by Pseudocalanus spp. in Shelikof Strait, Alaska. J. Plankton Res. 16: $1489-1498$

Sinclair, M. (1988). Marine populations: an essay on population regulation and speciation. University of Washington Press, Seattle, WA

Stoecker, D., Capuzzo, J. M. (1990). Predation on protozoa: its importance to zooplankton. J. Plankton Res. 12: $891-908$

Sundby, S., Fossum, P. (1990). Feeding conditions of ArctoNorwegian cod larvae compared with the RothschildOsborn theory on small-scale turbulence and plankton contact rates. J. Plankton Res. 12: 1153-1162

Sverdrup, H. U. (1953). On conditions for the vernal blooming of phytoplankton. J. Cons. int. Explor. Mer 18: 287-295

Taggart, C. T., Leggett, W. C. (1987). Short-term mortality in post-emergent larval capelin Mallotus villosus. II. Importance of food and predator density, and density-dependence. Mar. Ecol. Prog. Ser. 41: 219-229

Tate, M. W., Clelland, R. C. (1957). Nonparametric and shortcut statistics. Interstate Printers and Publ., Inc., Danville, IL

This article was submitted to the editor
Theilacker, G. H., Porter, S. M. (in press). Condition and shrinkage indices for larval walleye pollock, Theragra chalcogramma. Fish. Bull U.S

Thompson, A. B., Harrop, R. T (1991). Feeding dynamics of fish larvae on Copepoda in the western Irish Sea, with particular reference to cod Gadus morhua. Mar Ecol. Prog. Ser. $68 ; 213-223$

Tilseth, S., Ellertsen, B. (1984). The detection and distribution of larval Arcto-Norwegian cod, Gadus morhua, food organisms by an in situ particle counter. Fish. Bull. U.S. 82: $141-156$

Whitledge, T E., Molloy, S. C., Patton, C. J., Wirik, C. D. (1981). Automated nutrient analyses in seawater. Tech Rep. No. BNL-51398, Brookhaven National Laboratory, Upton, NY

Wilson, J. G., Overland, J. E. (1986). Meteorology. In: Hood, D. W., Zimmerman, S. (eds.) The Gulf of Alaska: physical environment and biological resources. Ocean Assessments Division/NOAA, Anchorage, AK, p. 31-54

Wooster, W. S., Bailey, K. M. (1989). Recruitment of marine fishes revisited. Can. Spec. Publ. Fish. Aquat. Sci. 108: 153-159

Yoklavich, M. M., Bailey, K. M. (1990). Hatching period, growth and survival of young walleye pollock Theragra chalcogramma as determined from otolith analysis. Mar. Ecol. Prog. Ser. 64: 13-23

Zar, J. H. (1984). Biostatistical analysis. Prentice-Hall, Englewood Cliffs, NJ

Manuscript first received: August 8, 1994

Revised version accepted: December 9, 1994 